\title{
The Contribution of Termitaria to Plant Species Conservation in the Pendjari Biosphere Reserve in Benin
}

\author{
H. O. Dossou-Yovo*, A. E. Assogbadjo, B. Sinsin \\ Laboratory of Applied Ecology, Faculty of Agronomic Sciences, University of Abomey-Calavi, Benin
}

Copyright $\subset 2016$ by authors, all rights reserved. Authors agree that this article remains permanently open access under the terms of the Creative Commons Attribution License 4.0 International License

\begin{abstract}
The role of termitaria in plant species diversity and conservation was investigated in Pendjari National Park and surroundings. The study objectives were to (i) compare termitaria vegetation similarity, life form and chorological composition between areas, (ii) investigate the difference of species richness and diversity on termitaria between living versus abandoned termitaria, and (iii) predict the species richness and diversity on termitaria as a function of termiaria size. Results show that species from the combretaceae family were the most abundant on termitaria; plant communities on termitaria were different among areas and between living and abandoned termitaria. Phanerophytes were abundant on mounds, therophytes were abundant on termitaria within the protected areas and farms outside of the park; however hemicryptophytes were as abundant as phanerophytes in fallows. From a phytogeographic perspective, species typical of Sudanian ecological region were the most abundant on termitaria. There was no difference in the richness and diversity of termitaria woody species, between termitaria state (dead or live) or between management type (protected or unprotected). Termitaria areas rather than termitaria height significantly correlated with the species richness and diversity. Larger termitaria had the highest diversity. Termitaria vegetation reflects the influence of local climate, moreover termitaria size can be used to predict the species richness and diversity related to them. The termitaria size has no influence on the richness and diversity of woody species related to them.
\end{abstract}

Keywords Termitaria, Plant Diversity, Ecology, Conservation, Pendjari National Park

\section{Introduction}

Termitaria play a key role in the maintenance of the tree diversity in savannah across West Africa [1-3], however our understanding of their contribution to the conservation of natural resources is still limited. Termite mounds occur in woodlands as well as agricultural land [4-6] in the tropical and subtropical regions where they constitute a typical feature [7-8]. Termitaria, colonised by various species of the fungus-growing termites (Isoptera; Macrotermitinae) occur at densities ranging between 2 to 7 mounds per ha [8]. The physical and chemical processes driven by termite regulate soil fertility around termite mounds [9]. During mound building, termites intensely modify soil properties, enriching the clay content and increasing soil infiltration capacities thus promoting microbial activity an improving nutrient composition and availability to plants [10-14]. As a consequence of this positive effect of termitaria on soils properties, there is often a high proportion of rapidly growing annual grasses and functionally-annual herbs around them, whereas slower growing perennial grasses and sedges are predominant far from them. For example, recent study in the sudanian region of Burkina-Faso [15] revealed that termitaria maintains higher tree species density compared to the surroundings. Furthermore, the diversity of species around termitaria was significant on sites subjected to fire and grazing. There is also evidence of termtiria effect on plant water economy strategy. For instance, Konaté et al [11] reported a lower dry season loss of leaves $(17 \%$ of leaves lost) by Crossopteryx febrifuga individuals occurring on mounds than those occuring far from it $(78 \%$ of leaves lost).

The type of termitaria as well as the higher diversity and density of plants around them may also affect the spatial distribution of wildlife. For instance, for nesting, females of Andros Iguana (Cyclura cyclura cyclura) select mounds with more than $5 \mathrm{~cm}$ surrounding soil depth [16]. Fleming and Loveridge also reported that small vertebrates heavily utilized Macrotermes mounds more than the surrounding miombo woodland in Zimbabwe [17]. Large ungulates often graze preferentially on mounds rather than on adjacent vegetation [18, 19]. In Benin, Attignon et al [20, 21] investigated the role of termites in nutrient recycling in natural and plantation forests and concluded that both changes in termite resource base and food-web disturbances affect termite assemblages.

In this study, we investigate the effect of land-use system on the diversity and functional role of termitaria-related 
vegetation. Specifically, we tested if species diversity, dominant life form and chorological composition of vegetation on termite mounds were different between the protected areas, farms and fallows in the Pendjari Biosphere reserve in Benin. We also tested if termitaria status (live or dead and abandoned by termites) and size affect plant species diversity.

\section{Materials and Methods}

\subsection{Study Area}

This study was conducted from July to October 2007 in the Pendjari Biosphere Reserve in Benin $\left(10^{\circ} 30^{\prime}-11^{\circ} 30 \mathrm{~N}\right.$, $0^{\circ} 50^{\prime}-2^{\circ} 00^{\prime}$ E, Fig. 1). The reserve covers 471,140 ha of which the Pendjari National Park covers approximately $56.47 \%$ and the Pendjari hunting zone only $43.53 \%$. The climate is dry with a single rainy season from mid-May to mid-October and an annual mean rainfall of $1000 \mathrm{~mm}$. The dry season starts from mid-October to mid-May. The annual mean temperature ranges between $18.6{ }^{\circ} \mathrm{C}$ and $36.8{ }^{\circ} \mathrm{C}$ in the northern Reserve and in the southern, between $20.5{ }^{\circ} \mathrm{C}$ and $34.2{ }^{\circ} \mathrm{C}$ [22]. Temperatures are highest in March and April and lowest from December to January. The vegetation consists of savannas, dry forest, woodlands and gallery forests dominated by Terminalia, Combretum and Acacia genera [23]. The most abundant species in shrub savanna are Combretum glutinosum, Crossopteryx febrifuga, Acacia seyal, Acacia senegal, Acacia gourmaensis [24]. Tree savannas are dominated by Acacia sieberiana, Pseudocedrela kotschyi, Terminalia macroptera, Detarium microcarpum, Burkea africana, Afzelia africana and
Vitellaria paradoxa. Lastly, gallery forests are mostly characterized by Diospyros mespiliformis, Borassus aethiopium, Ficus capensis, Khaya senegalensis, Parinari congoensis and Syzygium guineense. Thirteen ethnic groups in the Pendjari Biosphere Reserve were identified and their main income generating activities are agriculture, animal husbandry and trade.

\subsection{Data Collection}

We identified homogeneous sites using the soil, vegetation and rainfall maps of the Pendjari Biosphere Reserve. A total of 84 termitaria (28 per land-use type: protected areas, farms and fallows) were surveyed in the study. We installed $50 \mathrm{~m} \times 50 \mathrm{~m}$ plots to count and measure termite mounds. Mounds surveyed in the Pendjari National Park were mostly epigeal termitaria. Several authors $[13,25$, 26] identified them as Macrotermes genera buildings in tropical savannahs. The status of each mound (living or dead and abandoned) was assessed by slicing the mound to check for presence of termintes and by looking at its colour. Living mounds are mostly red while the dead and abandoned ones are black sometimes going to white. Geographical coordinates and altitude of each termitaria were recorded. Around each mound, a single plot of $900 \mathrm{~m} 2(30 \mathrm{~m} \times 30 \mathrm{~m})$ was established to record the existing woody species. The height and four radii of each termitaria were measured and the mean radius was used to calculate mound areas [19]. Plant species found on mound were identified and individuals' woody species counted. The plants species were identified at the National Herbarium of Université d'Abomey-Calavi (Benin).

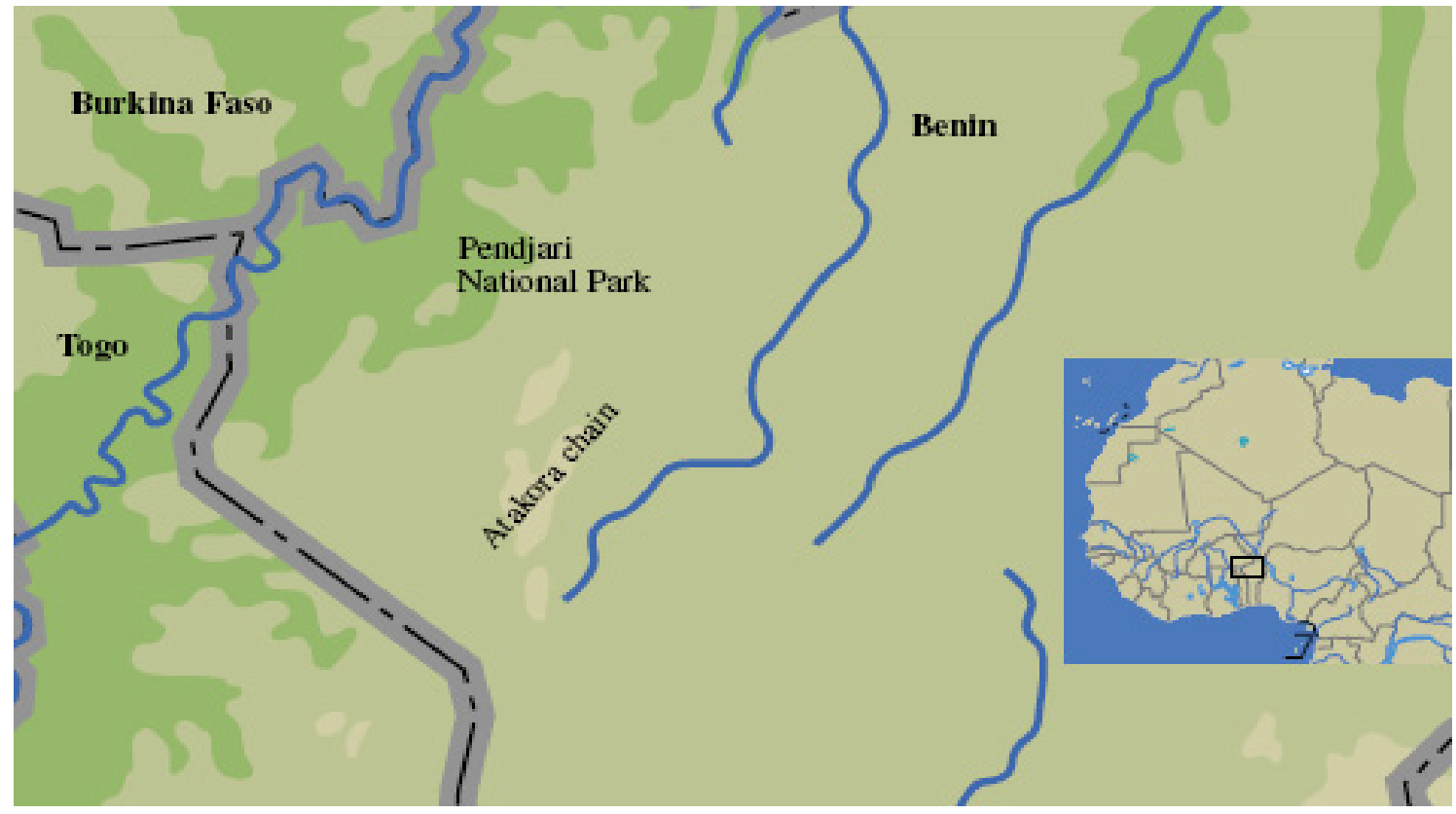

Figure 1. Location map of the biosphere reserve of Pendjari on the figure with the Atakora chain as southern border of the reserve, the Pendjari River the north-western border and the country boundaries marked in grey. 


\subsection{Data Analysis}

Plant communities established on the mounds were compared between land use type and status of termitaria using the Jaccard's similarity index $\mathrm{Ij}$ on species presence-absence data $[27,28]$. $\mathrm{Ij}$ is defined as follows:

$$
\mathrm{Ij}=\frac{\mathrm{c}}{\mathrm{a}+\mathrm{b}-\mathrm{c}} \times 100
$$

Where: $\mathrm{Ij}=$ Jaccard's similarity index, $\mathrm{a}=$ number of species found on mounds in land-use type $A ; b=$ number of species on mounds in land-use type $\mathrm{B}$ and $\mathrm{c}=$ number of species shared by A and B. Plant communities on mounds were considered similar if Ij was more than $50 \%$.

The dominant life form and phytogeographical spectra of termitaria vegetation were compared between land-use type and termitaria status. Woody and herbaceous species found on termitaria were taken to determine the life form and phytogeographical types of each species as indicated respectively by Sinsin [29], Houinato and Sinsin [30] and Adomou [31]. The main life forms used were: Th: Therophytes, Ch: Chamephytes, G: Geophytes Ph: Phanerophytes and Hc: Hemicryptophytes. About chorotypes, the following symbols were used: At: Atacorian species; PAL: Paleotropical species; Pt: Pantropical species; S: Sudanian species; SG: Guineo-congolian / Sudanian transition species and SZ: Sudano-zambesian species. The proportions of various life form and phytogeographical types were computed using the mound species checklists compiled for each area.

We calculated Shannon index $(\mathrm{H})$ and Evenness index (E) as follows:

$$
\begin{gathered}
\mathrm{H}=-\sum \mathrm{Pi} \log _{2} \mathrm{Pi} \\
\mathrm{E}=\mathrm{H} / \log _{2} \mathrm{~S}
\end{gathered}
$$

where $\mathrm{Pi}=$ proportion of individuals of species i per mound and $\mathrm{S}=$ woody species richness for each mound.

We used Kruskal-Wallis H-test to compare mean species richness, diversity parameters Shannon index $(\mathrm{H})$ and Evenness index (E) between land-use types and Mann-Whitney to test for differences in the parameters between live and dead abandoned termitaria. To test if species richness and diversity on termitaria were height or areas-dependent, we used linear regression. The dependent variables were the species richness and the diversity indices; mound height or areas were the independent variables. All statistical analyses were performed using SPSS 16.0 for Windows.

\section{Results}

\subsection{Species Composition}

The number of plant species recorded on termitaria varied among land-use types. The proportion of species restricted to termitaria as shown in Table 1 was higher in farms than in the Park and fallows.

Table 1. Number of plant species counted on termitaria per site categories and proportion of restricted species per area

\begin{tabular}{|c|c|c|c|c|}
\hline $\begin{array}{c}\text { Land-use } \\
\text { type }\end{array}$ & $\begin{array}{c}\text { Total } \\
\text { mounds } \\
\text { surveyed }\end{array}$ & $\begin{array}{c}\text { Woody } \\
\text { species } \\
\text { richness }\end{array}$ & $\begin{array}{c}\text { Total } \\
\text { species } \\
\text { richness }\end{array}$ & $\begin{array}{c}\text { Number and } \\
\text { percentage of } \\
\text { restricted } \\
\text { species }\end{array}$ \\
\hline Park & 28 & 37 & 49 & $5(13,5 \%)$ \\
\hline Fields & 28 & 42 & 74 & $11(26,2 \%)$ \\
\hline Fallows & 28 & 33 & 50 & $4(12,1 \%)$ \\
\hline
\end{tabular}

The lists and full names of plant species are available with the author.

Among the woody species found on termitaria, Combretaceae was overall dominant in all land-use types (Fig. 2). Species from the Rubiaceae family were co-dominant in the Park. In the farms, Mimosaceae ranked second whereas Caesalpiniaceae was co-dominant on mounds in fallows. The Shannon index and Evenness index showed similar trend and low diversity of termitaria-related woody species in our study areas (Table 2).

Table 2. Summary of Shannon and Evenness indices of termitaria surveyed in different site categories.

\begin{tabular}{|c|c|c|c|c|c|c|}
\hline \multirow{2}{*}{$\begin{array}{c}\text { Diversity } \\
\text { indices }\end{array}$} & \multicolumn{2}{|c|}{ Park } & \multicolumn{2}{c|}{ Fields } & \multicolumn{2}{c|}{ Fallows } \\
\cline { 2 - 6 } & Range & Mean \pm SD & Range & Mean \pm SD & Range & Mean $\pm S D$ \\
\hline $\begin{array}{c}\text { Shannon index } \\
\text { (Bits) }\end{array}$ & $0-2.32$ & $1.25 \pm 0.73$ & $0-2.95$ & $1.31 \pm 1$ & $0-2$ & $0.88 \pm 0.74$ \\
\hline Evenness index & $0-1$ & $0.80 \pm 0.38$ & $0-1$ & $0.66 \pm 0.44$ & $0-1$ & $0.58 \pm 0.45$ \\
\hline
\end{tabular}




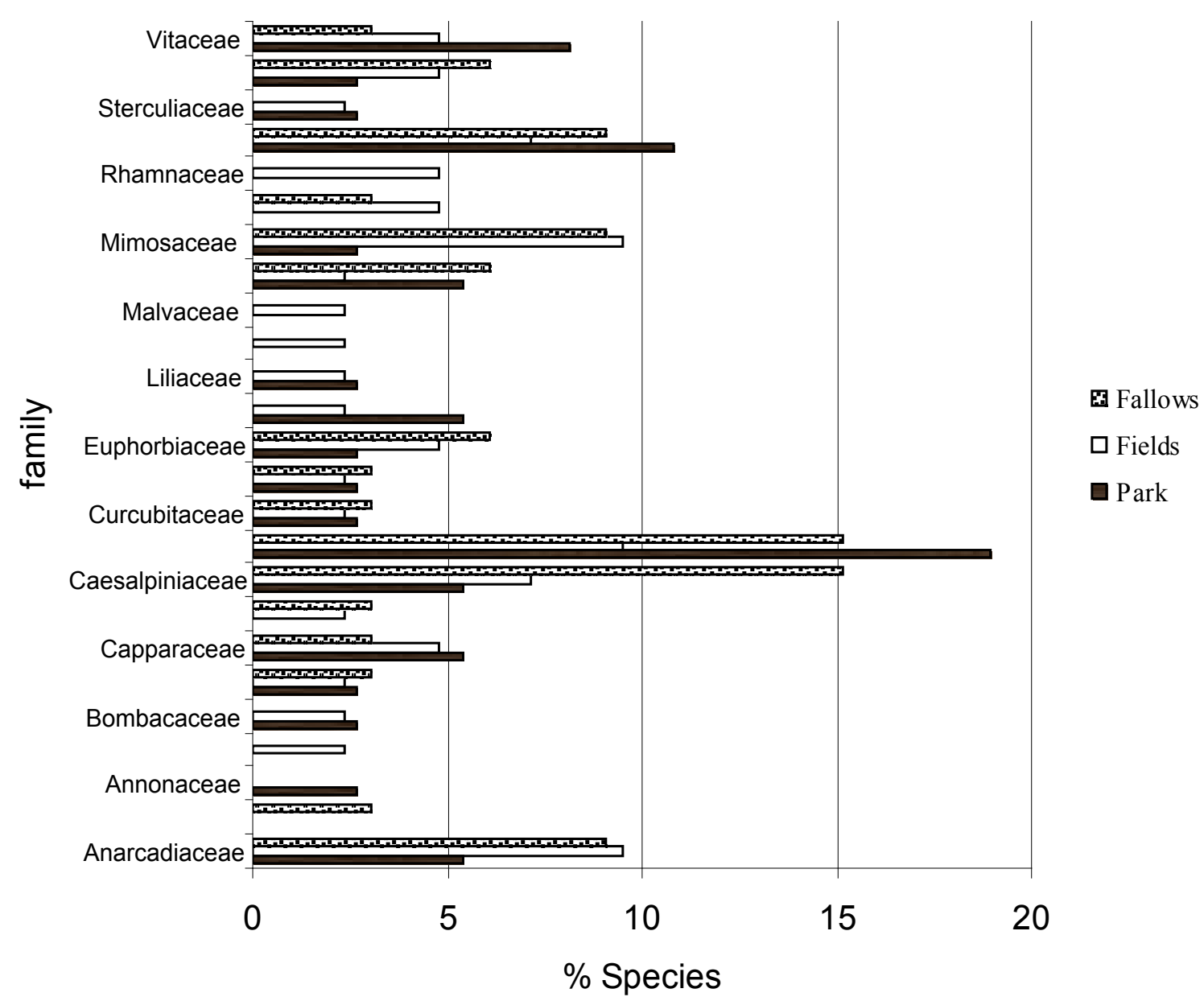

Figure 2. Plant family diversity and ranking by site category showing combretaceae species as the most abundant on termitaria whatever the area.

\subsection{Species Richness and Evenness Comparison}

There was no significant difference in species diversity between termitaria (Kruskal-Wallis, $p_{\text {richness }}=0.192$ ) and land-use types $\left(\mathrm{p}_{\text {shannon }}=0.07\right)$. However, the Evenness index of termitaria was different between sites categories (Kruskal-Wallis, $\mathrm{p}=0.03$ ). Furthermore, the Evenness mean rank for the three land-use types revealed highest evenness (best occupation of termitaria by species) in farms and the Park compared to fallows $\left(Z_{\text {Fallows }}=-3.06 ; Z_{\text {Fields }}=1.55\right.$ and $Z_{\text {Park }}=1.52$ ). For all site categories combined, there was no significant difference in species richness, as shown by both the Shannon and Evenness indices between living and abandoned termitaria (Mann Whitney, $\mathrm{p}_{\text {richness }}=0.66 ; \mathrm{p}_{\text {shannon }}$ $=0.56$ and $p_{\text {evenness }}=0.82$ ).

\subsection{Correlation between Mound Size and Species Diversity}

There was no significant correlation between termitaria height and species richness and diversity whereas mound surface area was positively correlated with the above-mentioned parameters [Linear regression of surface area with (i) species richness: $p=0.03$ and $\mathrm{R}^{2}=10.6 \%$; (ii) Shannon index: $p=0.03$ and $R^{2}=10.4 \%$; Evenness: $p=0.20$ and $\left.\mathrm{R}^{2}=6.5 \%\right]$.

\subsection{Comparison of Plant Communities}

Jaccard's values were lower than $50 \%$ for all land-use types but the comparison between farms and fallows revealed the highest values of Jaccard's index for both woody communities and the total termitaria flora. So, termitaria in farms and fallows had more species in common compared with the mounds vegetation in the Park. For all category sites, woody species on abandoned termitaria (46 species) were significantly different $(\mathrm{Ij}=43.07 \%)$ from living termitaria (47 species).

\subsection{Life form Spectrum}

Phanerophytes were the most abundant on mounds. Among herbaceous species, therophytes were the most abundant on mounds in the Park, farms and fallows. Hemicryptophytes were co-abundant with therophytes on termitaria in fallows.

\subsection{Chorological Spectrum}

Sudano-zambesian species were the most abundant on mounds in the Park whereas in farms and fallows, sudanian species were the most abundant. In total, species of sudanian chorological group consisted of Sudanian and 
Sudano-Zambesian were the most abundant on mounds in our study areas.

\section{Discussion}

\subsection{Species Composition and Diversity}

With respect to species restricted to termitaria, Cadaba farinosa (Capparaceae) was also reported on mounds by Traoré et al [15]. The latter had mentioned the genera Capparis and Maerua (both Capparaceae) as solitary on mounds. In addition, Arbonnier [32] mentioned termitaria as Capparaceae's habitat. Results from our investigation and mentioned studies show termitaria to be hotspots for Capparaceae species [15, 32]. Indeed, Arbonnier [32] also mentioned dry stations and rocky soils and mountains among Capparaceae's habitat. As a result, we assume that there are some similar patterns between types of termitaria on which these species grow and the other habitat types where the species are found. An investigation can be undertaken to state this similarity.

The abundance of Combretaceae species on termitaria (Fig. 2) is consistent with the results of Thiombiano et al [33] who reported an increased number of Combretaceae species in Burkina Faso. Similarly, Traoré et al [15] identified Combretaceae, Mimosaceae, Rubiaceae and Caesalpiniaceae as predominant families on termitaria. So Combretaceae species seem dominant on termitaria in sudanian regions and this finding could be explained by the compliance of vegetation with climatic conditions. The implication of this result for conservation and vegetation sampling is the conservation of the concerned species through the sustainable management of termitaria. In addition, termite mounds can serve as hotspots for Combretaceae sampling in sudanian regions and further researches can be conducted to highlight the ecological patterns responsible of Combretaceae distribution on termitaria in sudanian savannahs.

The low values of Shannon index (Table 2) may be explained by the fact that termitaria are selective habitats. In other words, they may be some specific plant species having termitaria as habitats and these species are poorly diversified and this fact leads to low termitaria species diversity.

\subsection{Species Diversity and Termitaria Size}

Our study reveals no significant effect of termitaria status on plant species richness and diversity. This is consistent with findings by Traoré et al [15] in similar ecological settings. However, termitaria status tends to influence their floristic composition. Specifically, we found that species such as Maerua oblongifolia, Flueggea virosa and Feretia apodanthera were more abundant on abandoned mounds while Detarium microcarpum, Combretum molle and Diospyros mespiliformis were observed on live termitaria (complete list of species rank-abundance available with author). With regards to the habitat of the three species found on abandoned mounds according to Arbonnier [32], F. virosa abundant on abandoned mounds is characteristic of disturbed habitats while $F$. apodanthera is said to colonize compact and battleship soils. M. oblongifolia is found on all types of soil. We assume in this study that these species have in common the disturbed and poor habitat since compact and battleship soils mentioned above are mostly poor in terms of fertility. Abandoned and dead mounds are consequently seen as disturbed habitats in this paper but this has not been stated yet.

Similarly to our findings, many other authors reported the independence between land-use type on mean species richness and diversity [34-36].

Moreover, termitaria areas can be used to predict a part of plant species richness and diversity on mounds. This positive relation is consistent with the findings of Harner and Harper [37]. Chapin III et al [38] reported that several experiments indicate linear and asymptotic relationship of ecosystem process rates with species richness. So as long as termitaria are conserved, termite species will be conserved. Consequently the building activities may lead to increasing termitaria areas. The implication of this latter for conservation is that the probability of species occurrence with strong ecosystem effects will increase. In contrast to the positive relation between termitaria areas and species evenness found in our study areas, Hurlbert [39] found that species evenness tends to decrease with sample size. The low values obtained for the coefficient of determination $\left(R^{2}\right)$ suggest that a little part of the variation of plant species richness and diversity was explained by surface variation. Therefore, other additional ecological factors such as chemical characteristics of mounds and the annual rainfall received by termitaria, may have contributed to plant species richness and diversity on termitaria. Regardless of all other factors susceptible of influencing plant species richness and diversity in relation with termitaria, results highlighted in this paper allow us to conclude that termitaria conservation will lead to increasing species richness and diversity since they increase with termitaria surface.

Finally, we suggest that further studies focusing on the spatial distribution of termitaria and variation in their size be done. Studies on the variation in species diversity related to the distribution of termitaria could serve to predict the spatial heterogeneity of microhabitats and its impact on plant species diversity in semi-arid ecosystems.

\subsection{Comparison of Plant Communities}

Plant communities on mounds were different among land-use types $(\mathrm{Ij}<50 \%)$. Termitaria in the various areas offer various floristic compositions. The assumption is that the ecological factors which determine species distribution on termitaria seem to be different between management areas. For example, the dissimilarity in floristic composition between land-use types may reflect the difference in dispersal agents between areas. Farms and fallows are easily 
accessible to people and domestic animals contrary to the Park wherein wild animals are predominant. As a result, wild and domestic animals as well as humans will transport different diaspores cross termitaria in investigated areas. The fact that termitaria in fields and fallows shared more species $(\mathrm{Ij}=47.1 \%)$ may probably be due to the effect of the common diaspores transport agents in these areas and other factors such as wildland fire. Traoré et al [15] stated the positive effect of fire and livestock grazing on tree density found on termitaria but no investigation has been directed to measure the impact of these factors on termitaria floristic composition.

\subsection{Termitaria Life Forms and Phytogeography}

Life form spectra reflect not only the sum of ecological factors, including climate and human influences, but the historical factors of transport and introduction of new species from abroad [40] Here we do not focus discussion on climatic factors since they are not measured in this study. However, we assumed that as termitaria are located in the same bioclimatic zone, climate influence may be less important. The importance of therophytes on termitaria in fields might be due to the fact that after ploughing or weeding farms, farmers put heaps on termite mounds. The herbs mostly consist of therophytes of seed origin. Elsewhere, animals and humans contribute also to the abundance of therophytes [40-41]. In savannah ecosystems, termitaria are browsing spots for megaherbivores [14-19]. Some animal species such as lions (Panthera leo) eat their prey on termitaria whereas other animal species get rest on mounds (example hyena: Crocuta crocuta; unpublished data). Despite the likely low disturbance on termitaria in the National Park compared to farms, all the actions highlighted above could contribute to the abundance of therophytes on termitaria within the National parks.

The importance of sudanian species on mound reflects the effect of climate [28-33]. This confirms the fact that the specific plant composition of termitaria and their physiognomy vary between phytogeographical regions [15-17, 42, 43, 44]. The abundance of sudanian species confirms the compliance of termitaria flora with the study area which is a sudanian zone. The sustainable management of termitaria will consequently contribute to sudanian species conservation in the Pendjari Biosphere Reserve.

\section{Acknowledgements}

This work was financially supported by BIOTA. We thank this institution and its donors. Our acknowledgements also go to local communities around the National Park of Pendjari, Dr. Aristide Adomou (National Herbarium, University of Abomey-Calavi Benin) and Aristide Tehou (Pendjari National Park). We are also grateful to Orou Gaoué (PhD) and Cuthbert Katsvanga for editing the draft of this paper.

\section{REFERENCES}

[1] M. Grouzis, Structure, Productivité et Dynamique des Systèmes Ecologiques Sahéliens (Mare d'Oursi, Burkina Faso). ORSTOM, Paris, 1988, p. 139.

[2] M. Larwanou, Rapport Technique d'Activite's. Institut National de la Recherche Agronomique du Niger, 1998, p. 58.

[3] L. Mahamane and S. Mahamane, Biodiversity of tree species in semi-arid to arid zones of southwestern Niger according to anthropogenic and natural factors. Agr. Ecosyst. Environ. 105 (2005) 267-271.

[4] Y. Tano, Les termitières épigées d'un bassin versant en savane soudanienne : Répartition et dynamique des nids, rôle sur les sols et la végétation. Doctoral Thesis, Université Nationale de Côte d'Ivoire, Abidjan, 1993.

[5] H.I.J. Black and M.J.N. Okkwakol, Agricultural intensification, soil biodiversity and agro ecosystem function in the tropics: the role of termites. Appl. Soil Ecol. 6 (1997) 37-53.

[6] M. Lepage and J.P.E.C. Darlington, Population dynamics of termites. In: T. Abe, D. E. Bignell and M. Higashi (Eds), Termites: Evolution, Sociality, Symbioses, Ecology, Kluwer Academic Publishers, Dordrecht, 2000, pp. 333-361.

[7] W.V. Harris, The role of termites in tropical forestry. Insect. Soc. 13 (1966) 255-266.

[8] K.E. Lee and T.G. Wood, Termites and Soils. Academic Press, London, 1991.

[9] K.E. Lee and R.C. Foster, Soil fauna and soil structure. Aust. J. Soil Res. 29 (1991) 745-775.

[10] C.G. Jones, J.H. Lawton and M. Shachak, Organisms as ecosystems engineers. Oïkos 69 (1994) 373-386.

[11] S. Konate, X. LeRoux, D. Tessier and M. Lepage, Influence of large termitaria on Soil characteristics, Soil water regime, and tree leaf shedding pattern in West African savanna. Plant and Soil 206 (1999) 47-60.

[12] J.A. Holt and M. Lepage, Termite and Soil Properties. In: T. Abe, D.E. Bignell, M. Higashi (Eds) Termites: evolution, sociability, symbiosis, ecology, Kluwer, Dordrecht 2000, pp. 389-407.

[13] P. Jouquet, D. Tessier and M. Lepage, The soil structural stability of termite nests: role of clay in Macrothermes bellicosus (Isoptera, Macrotermitinae) mound soil. European Journal of Soil Biology 40 (2004) 23-29.

[14] A.V. Spain and J.G. McIvor, The nature of Herbaceous Vegetation Associated with Termitaria in North-Eastern Australia. The Journal of Ecology 76 (1988) 181-191.

[15] S. Traoré, R. Nygard, S. Guinko, et al. Impact of Macrotermes termitaria as a source of heterogeneity on tree diversity and structure in a Sudanian savannah under controlled grazing and annual prescribed fire (Burkina-Faso), Forest Ecology and Management 255 (2008) 2337-2346.

[16] C.R. Knapp and A.K. Owens, Nesting Behavior and the Use of Termitaria by the Andros Iguana (Cyclura cychlura cychlura). Journal of Herpetology 42 (2008) 46-53.

[17] P.A. Fleming and J.P. Loveridge, Miombo woodland termite mounds: resource islands for small vertebrates? J. Zool. Lond. 
259 (2003) 161-168.

[18] R. Mobæk, A.K. Narmo and S.R. Moe, Termitaria are focal feeding sites for large ungulates in Lake Mburo National Park, Uganda. Journal of Zoology 267 (2005) 97-102.

[19] J.P. Loveridge and S.R. Moe, Termitaria as browsing hotspots for African megaherbivores in miombo woodland. J. Trop Ecol. 20 (2004) 337-343.

[20] S. E. Attignon, D. Weibel, T. Lachat., et al. Leaf litter breakdown in natural and plantation forests of the Lama Forest reserve in Benin. Appl. Soil Ecol 27 (2004) 109-124.

[21] S.E Attignon, T. Lachat, B. Sinsin, et al. Termite assemblages in a west-African semi-deciduous forest and teak plantations. Agric. Ecosyst. Environ 110 (2005) 318-326.

[22] E.A. Sogbohossou, Etude des conflits entre les grands carnivores et les populations riveraines de la réserve de biosphère de la Pendjari, nord Bénin. MAB UNESCO Bourse Jeunes Chercheurs, 2004, p. 24.

[23] B. Sinsin, A. Seidou, A. Tehou, et al. Dénombrement de la faune dans la Réserve de Biosphère de la Pendjari. Rapport technique, CENAGREF, Projet Pendjari-GTZ, Bénin, 2000, p. 54.

[24] MAB/UNESCO Pendjari (Bénin). Contribution aux études d'aménagement du Parc National et de sa zone périphérique. 1990, p. 125.

[25] E. Garnier-Sillam, E. Braudeau and D. Tessier, Rôle des termites sur le spectre poral des sols forestiers tropicaux. Cas de Throracotermes macrothorax Sjöstedt (Termitinae) et de Macrothermes mülleri (Sjöstedt) (Macrotermitinae). Ins. Soc. 38 (1991) 397-412.

[26] P. Jouquet, T. Mery, C. Rouland, et al. Modulated effects of the termite Ancistrotermes cavithorax (Isoptera, Macrotermitinae) on soil properties according to the internal mounds structures; Sociobiology 42 (2003) 403-412.

[27] R. Real and J. M.Vargas, The probabilistic Basis of Jaccard's Index of Similarity. Systematic Biology 45 (1996) 380-385.

[28] C.A. Adomou, B. Sinsin and L.J. G.van der Maesen, Phytosociology and chorological approaches to phytogeography: a meso-scale study in Benin. Syst. Geogr. Pl. 76 (2006) 155-178.

[29] B. Sinsin, Phytosociologie, écologie, valeur pastorale, production et capacité de charge des pâturages naturels du nord-Bénin. Thèse de doctorat. Université Libre de Bruxelles, 1993, p. 390.

[30] M. Houinato and B. Sinsin, Analyse phytosociologique de la région des Monts Kouffé au Bénin. Syst Geogr. Pl. 71 (2001)
889-910.

[31] C.A. Adomou, Vegetation patterns and environmental gradients in Benin Implications for biogeography and conservation. Thèse de doctorat, Wageningen Pays Bas. ISBN 90-8504-308-5. 2005, p. 135.

[32] M. Arbonnier, Arbres, Arbustes et Lianes des Zones Sêches de l'Afrique de l'Ouest, CIRAD, MNHN, UICN, Montpellier, France, 2000, p. 573.

[33] A. Thiombiano, S. Schmidt, H. Kreft, et al. Influence du gradient climatique sur la distribution des espèces de Combretaceae au Burkina-Faso (Afrique de l'Ouest). Candollea, ISSN: 0373-296761. 2006, p. 27.

[34] J.S. Denslow, Patterns of plant species diversity during succession under different disturbance regimes. Oecologia 46 (1980) 18-21.

[35] R.J. Hobbs and L.F. Huenneke, Disturbance, Diversity, and Invasion: Implications for Conservation. Conservation Biology 6 (2002) 324-337.

[36] B.P. Mishra, O.P. Tripathi, R.S. Tripathi, et al. Effects of anthropogenic disturbance on plant diversity and community structure of a sacred grove in Meghalaya, northeast India. Biodiversity and conservation 13 (2004) 421-436.

[37] R.F. Harner and K.T. Harper, The Role of Area, Heterogeneity, and Favorability in Plant Species Diversity of Pinyon-Juniper Ecosystems. Ecology 57 (1976) 1254-1263.

[38] F.S. Chapin III, E.S. Zavaleta, V.T. Eviner, et al. Consequences of changing biodiversity. Nature 45 (2000) 234-242.

[39] S.H Hurlbert, The nonconcept of species diversity: A critique and alternative parameters. Ecology 52 (1971) 577-586.

[40] K. Lems, Botanical notes on the Canary Islands. III. The life form spectrum and its interpretation. Ecology 42 (1961) 569-572.

[41] B. Sinsin, Formes de vies et diversité spécifique des associations de forêts claires dans le Nord Bénin. Syst. Geogr. P1. 71 (2001) 873-888.

[42] D.B. Fanshawe, The vegetation of Zambian termitaria. Kirkia 6 (1968) 169-180.

[43] P.E. Glovers, E.C. Trump and L.E.D Wateridge, Termitaria and vegetation patterns on Loita plains of Kenya. J. Ecol. 52 (1964) 367-375.

[44] P. Ouédraogo, Rôle des termitières dans la Structure et la Dynamique d'une brousse tigrée Soudano sahélienne. PhD thesis, Université Pierre et Marie Curie, Paris VI, 1997. 